\title{
Schadeveroorzakende toestanden
}

\author{
Wanneer begint de lange verjaringstermijn van twintig jaar te lopen bij een vordering op \\ grond van art. 6:174 $\mathrm{BW}$ ?
}

\author{
Mr. B.T. Berends en mr. P.W. den Hollander*
}

\section{De Zandvoortse muur}

Een rechtsvordering tot vergoeding van schade verjaart 'in ieder geval' door verloop van twintig jaar na de gebeurtenis waardoor de schade is veroorzaakt, aldus art. 3:310 lid 1 Burgerlijk Wetboek (BW). Maar wat als een gebrekkige opstal gedurende tientallen jaren in een doorlopend proces schade veroorzaakt? Wanneer begint de lange verjaringstermijn dan te lopen? Over die vraag sprak de Hoge Raad zich uit in zijn arrest van 22 maart 2019.

De feitelijke achtergrond van dit arrest is een muur in Zandvoort, naast een buitentrap van een parkeergarage. Als in april 2015 een verontruste bewoner bij de gemeente meldt dat de muur scheef staat, draagt die de eigenaar van de muur - de vereniging van eigenaren van de parkeergarage waartoe de muur behoort (hierna: de parkeergarage) - op de situatie 'op te lossen'. De muur wordt door een aannemer deels afgebroken. Een ingeschakelde deskundige constateert dat de scheefstand is veroorzaakt door gronddruk vanuit het naastgelegen perceel. Daarop is in 1974 een oprit aangelegd naar parkeerplaatsen bij een flatgebouw die zich anderhalve meter boven straatniveau bevinden. De deskundige adviseert de oprit te voorzien van een nieuwe grondkerende constructie. Op 21 mei 2015 stelt de parkeergarage de eigenaar van de oprit - de vereniging van eigenaren van het flatgebouw waartoe de oprit behoort (hierna: het flatgebouw) - aansprakelijk. Het komt tot een procedure bij de Rechtbank Noord-Holland. De parkeergarage vordert schadevergoeding op grond van de risicoaansprakelijkheid voor opstallen van art. 6:174 BW, stellend dat de oprit gebrekkig is nu deze niet is voorzien van een grondkerende constructie. Het flatgebouw betwist deze gebrekkigheid en verweert zich met (onder meer) een beroep op verjaring.

Het flatgebouw beroept zich in de eerste plaats op de korte, subjectieve verjaringstermijn van vijf jaar. Dat biedt het flatgebouw geen soelaas. Deze vijfjaarstermijn begint te lopen op de dag volgende op die waarop de benadeelde zowel met de schade als met de daarvoor aansprakelijke persoon bekend is

\footnotetext{
Mr. B.T. Berends is advocaat bij Stibbe in Amsterdam. Mr. P.W. den Hollander is advocaat bij Stibbe in Amsterdam en redacteur van dit tijdschrift.
}

geworden. ${ }^{1}$ Het gaat hierbij om daadwerkelijke bekendheid. ${ }^{2}$ Het flatgebouw betoogt dat uit foto's uit 2011 volgt dat de scheefstand op dat moment al jaren zichtbaar was, en dat de parkeergarage dus al jaren voor 2011 bekend was met de schade (en ook dan bekend zou zijn geworden met het flatgebouw als aansprakelijke persoon). De vijfjaarstermijn zou daarom al zijn voltooid op het moment dat de parkeergarage haar aansprakelijkstelling uitbracht. Rechtbank en hof gaan hierin niet mee. De rechtbank wijst een tussenvonnis en verwerpt het beroep van het flatgebouw op de vijfjaarstermijn. Dat doet ook het hof in het hoger beroep van dit tussenvonnis. Zelfs als op die foto's een 'aanzienlijke' scheefstand zichtbaar zou zijn, zo overweegt het hof, dat de foto's 'niet heel duidelijk acht', dan betekent dat nog niet dat de parkeergarage enkel op grond daarvan daadwerkelijk bekend was met haar schade. ${ }^{3}$ A-G Valk constateert dat het hof de 'sprong' van kenbaarheid van de schade naar daadwerkelijke bekendheid met de schade niet heeft willen maken en dat dit een oordeel is dat in beginsel is voorbehouden aan het hof als feitenrechter. Hij acht het oordeel van het hof voldoende gemotiveerd en niet onbegrijpelijk. ${ }^{4}$ De Hoge Raad verwerpt de klachten van het flatgebouw

1. Zie voor een uitgebreide bespreking van het aanvangsmoment van de korte verjaringstermijn de eerder in dit tijdschrift verschenen bijdrage J.M. Fluitsma \& R.D. Lubach, Wanneer start de korte verjaringstermijn?, MvV 2017, afl. 9, p. 257-262.

2. Zie met betrekking tot het vereiste van daadwerkelijke bekendheid M.W.E. Koopmann, Bevrijdende verjaring (Mon. BW nr. B14), Deventer: Kluwer 2010/19.6; HR 6 april 2001, ECLI:NL:HR:2001:AB0900, NJ 2002/383 (Vellekoop/Wilton Feijenoord); vgl. ook HR 20 april 2001, NJ 2002/384 (Wong/mr. X); HR 24 januari 2003, ECLI:NL:HR: 2003:AF0694, NJ 2003/300 (BASF/Rensink); HR 4 mei 2012, ECLI:NL:HR:2012:BV6769, NJ 2016/197 m.nt. C.E. du Perron (Huisman q.q./Hoskens), r.o. 3.4.3; en recenter HR 31 maart 2017, ECLI:NL:HR:2017:552, NJ 2017/165 (Mispelhoef/Staat). De uitleg die de Hoge Raad geeft aan het begrip bekendheid makt dat het enkele vermoeden van het bestaan van schade niet volstaat en dat in beginsel op de gelaedeerde geen onderzoeksplicht rust, aldus Asser/Sieburgh 6-II $2017 / 415$.

3. Hof Amsterdam 23 januari 2019, ECLI:NL:GHAMS:2018:249, r.o. 3.4.2. Het hof acht een aanzienlijke scheefstand - als die dus zichtbaar zou zijn op de foto's - 'nog niet voldoende' voor het oordeel 'dat het niet anders kan zijn' dan dat de parkeergarage vijf jaar voor de aansprakelijkstelling van 21 mei 2015 al met de schade bekend is geweest. Daarbij betrekt het hof dat het flatgebouw geen andere feiten of omstandigheden heeft gesteld naast de foto's.

4. Conclusie A-G Valk 21 december 2018, ECLI:NL:PHR:2018:1433, sub 3.5. 
tegen dit oordeel op grond van art. 81 Wet op de rechterlijke organisatie (Wet RO). 5

In het arrest van de Hoge Raad komt daardoor alleen het beroep van het flatgebouw op de lange, objectieve verjaringstermijn van twintig jaar inhoudelijk aan de orde. In deze bijdrage bespreken wij het oordeel van de Hoge Raad over deze twintigjaarstermijn. Dat oordeel is om verschillende redenen opvallend. Het hof komt tot het oordeel dat de schadevergoedingsvordering van de parkeergarage gedeeltelijk is verjaard. In cassatie klaagt het flatgebouw dat het hof had moeten oordelen dat deze vordering in het geheel is verjaard. De Hoge Raad verwerpt de klachten, maar geeft vervolgens nog twee overwegingen ten overvloede. Daaruit volgt - als wij die overwegingen goed begrijpen - dat naar het oordeel van de Hoge Raad de schadevergoedingsvordering van de parkeergarage niet gedeeltelijk, niet integraal, maar in het geheel niet is verjaard. De Hoge Raad overweegt namelijk dat 'in een geval als dit' omwille van de rechtszekerheid moet worden aangenomen dat de twintigjaarstermijn gaat lopen zodra de schadeveroorzakende gebeurtenis 'is opgehouden te bestaan'. In feite corrigeert de Hoge Raad het hof dus na verwerping van de cassatieklachten alsnog en ongevraagd, want de parkeergarage had tegen het oordeel van het hof geen cassatieberoep ingesteld. Het oordeel van het hof dat de schadevergoedingsvordering van de parkeergarage gedeeltelijk is verjaard, blijft daarom dus in stand. $\mathrm{Zij}$ het vooralsnog, want na het arrest van de Hoge Raad zijn partijen weer terug bij de rechtbank, na het tussenvonnis.

Ook inhoudelijk is het oordeel van de Hoge Raad over de twintigjaarstermijn opvallend, meer specifiek zijn oordeel over de vraag wanneer die termijn in een geval als dat van de Zandvoortse muur begint te lopen. De Hoge Raad zoekt aansluiting bij de regeling voor aanvang van de lange verjaringstermijn in gevallen van milieuverontreiniging in art. 3:310 lid $3 \mathrm{BW}$, onder nuancering van zijn oordeel in het kindermishandelingsarrest uit 1999 dat deze regeling niet buiten gevallen van milieuverontreiniging mag worden toegepast. Om het arrest goed te kunnen duiden, resumeren wij daarom eerst kort de stand van literatuur en rechtspraak over de aanvang van de twintigjaarstermijn van art. 3:310 lid $1 \mathrm{BW}$ tot aan het arrest over de Zandvoortse muur (par. 2). Hierna bespreken wij achtereenvolgens de uiteenlopende benaderingen die de rechtbank, het hof en advocaat-generaal Valk kiezen bij de vraag wat in deze Zandvoortse muur-zaak moet worden aangemerkt als schadeveroorzakende gebeurtenis in de zin van art. 3:310 lid $1 \mathrm{BW}$ en wanneer de twintigjaarstermijn is gaan lopen (par. 3 en 4). Tegen deze achtergrond bespreken wij het oordeel van de Hoge Raad in meer detail (par. 5) en geven wij onze observaties over zijn implicaties (par. $6 \mathrm{t} / \mathrm{m} 8$ ).

5. HR 22 maart 2019, ECLI:NL:HR:2019:412, RvdW 2019/394 (Zandvoortse muur), r.o. 3.4.

\section{Rechtspraak en literatuur over aanvang van de twintigjaarstermijn tot de Zandvoortse muur}

Aan de lange verjaringstermijn van twintig jaar ligt het belang van rechtszekerheid ten grondslag. Het gaat om de rechtszekerheid dat na verloop van twintig jaar vanaf een objectief vast te stellen moment een schadevergoedingsvordering niet meer kan worden ingesteld en de schuldenaar niet meer kan worden aangesproken met een beweerdelijke schadevergoedingsvordering waarvan hij mogelijk het bestaan niet kent. Een belangrijke achterliggende ratio is dat na twintig jaar de feiten en verwijten die aan de vordering ten grondslag liggen door tijdsverloop mogelijk niet meer goed kunnen worden beoordeeld. ${ }^{6} \mathrm{De}$ wetgever wijst erop dat het onredelijk is te verwachten dat administraties zo lang bewaard worden, dat er met het verstrijken van de tijd geen getuigen meer (te achterhalen) zijn, en dat de waarde van dit getuigenbewijs door het falende menselijke geheugen sterk verminderd zal zijn. ${ }^{7}$ Ook zal de vermogenspositie van de schuldenaar met het verstrijken van de tijd niet meer zijn ingesteld op een vordering van de schuldeiser. ${ }^{8}$

Anders dan de korte vijfjaarstermijn in art. 3:310 lid $1 \mathrm{BW}$ gaat de twintigjaarstermijn daarom lopen onafhankelijk van de kennis van de betrokken partijen, namelijk 'na de schadeveroorzakende gebeurtenis'. $\mathrm{Om}$ vast te stellen wanneer in een geval als dat van de Zandvoortse muur de twintigjaarstermijn gaat lopen, is dus allereerst de vraag wat onder zo'n gebeurtenis moet worden verstaan. Voorafgaand aan het arrest van de Hoge Raad in de zaak van de Zandvoortse muur kwam die vraag aan de orde in het arrest Van Hese/De Schelde. Werknemer Van Hese sprak zijn werkgever De Schelde aan op de grond dat hij ten onrechte was blootgesteld aan asbest tijdens zijn werk en daardoor mesothelioom had opgelopen. Die ziekte openbaarde zich echter pas tientallen jaren later. ${ }^{10} \mathrm{De}$ Hoge Raad oordeelde dat deze blootstelling gold als schadeveroorzakende gebeurtenis in de zin van art. 3:310 lid 1 BW, ook al resulteerde deze niet direct in de schade. De Hoge Raad legde dit begrip uit als de gedraging van de aansprakelijke

6. Zie bijv. Asser/Sieburgh 6-II 2017/381-383, HR 3 november 1995 ECLI:NL:HR:1995:ZC1867, NJ 1998/380 m.nt. C.J.H. Brunner (Van B./Diaconessenarbeid), r.o. 3.4 en HR 28 april 2000, ECLI:NL:HR: 2000:AA5635, NJ 2000/430 m.nt. A.R. Bloembergen (Van Hese/De Schelde), r.o. 3.3.1.

7. Kamerstukken II 1991/92, 22599, 3 (MvT). Zie tevens R.P.J.L. Tjittes, Bevrijdende verjaring: van rechtszekerheid naar billijkheid, WPNR 2002/6472, p. 53 en J.L. Smeehuijzen, Verjaring van het recht op vergoeding van personenschade, Den Haag: Boom Juridische uitgevers 2006 , p. 10. Medische dossiers hoeven bijv. slechts vijftien jaar bewaard te blijven.

8. M.A. Loth e.a., Recht over tijd: hoe ver reikt het privaatrecht in het verleden?, Zutphen: Uitgeverij Paris 2018, p. 19-20.

9. Zie HR 25 juni 1999, ECLI:NL:HR:1999:ZC2934, NJ 2000/16 m.nt. A.R. Bloembergen (Kindermishandeling), r.o. 5.1: '(...) voor het aanvangstijdstip van de twintigjarige verjaring is beslissend het objectief gegeven tijdstip waarop de gebeurtenis plaatsvond waardoor de schade is veroorzaakt'. Zie ook HR 3 november 1995, ECLI:NL:HR:1995:ZC1867, NJ 1998/380 m.nt. C.J.H. Brunner (Van B./Diaconessenarbeid), r.o. 4.3.2.

10. Zie voor meer en uitgebreider over het arrest Van Hese/De Schelde o.a. Smeehuijzen 2006, p. 56 e.v. en Loth e.a. 2018, p. 24 e.v. 
persoon die tot de schade waarvan vergoeding wordt gevorderd, kan leiden:

'Op grond van de tekst van deze bepaling en de wetsgeschiedenis, zoals weergegeven in de conclusie van de Advocaat-Generaal Spier onder 6.6 - 6.11, moet worden aangenomen dat als gebeurtenis heeft te gelden de gedraging - handelen of nalaten - van de aansprakelijke persoon, die tot de schade kan leiden, ook al is het vooralsnog onzeker of inderdaad schade een gevolg ervan zal zijn en al heeft de schade, indien zij zich voordoet, zich pas later gemanifesteerd.' ${ }^{11}$

Staat vast wat de schadeveroorzakende gebeurtenis is, dan is vervolgens de vraag wanneer die eindigt. De twintigjaarstermijn begint immers te lopen na de schadeveroorzakende gebeurtenis. Dat lijkt niet ingewikkeld en dat is het ook niet, mits de schadeveroorzakende gebeurtenis slechts korte tijd voortduurt. Vaste, algemene regels hoe om te gaan met een schadeveroorzakende gebeurtenis die langer voortduurt en zelfs - zoals in de zaak van de Zandvoortse muur - (veel) langer dan de twintigjaarstermijn zelf, zijn er niet. ${ }^{12}$

Art. 3:310 BW bevat in lid 2 en 3 wel een specifieke regeling voor verjaring van rechtsvorderingen ter zake van milieuverontreiniging. ${ }^{13}$ Preciezer gezegd gaat het dan om rechtsvorderingen ter zake van verontreiniging van bodem, lucht en water en schade door gevaarlijke stoffen in de zin van art. 6:175 BW en mijnbouw in de zin van art. 6:177 BW. ${ }^{14}$ Daarvoor geldt geen twintigjaarstermijn, maar een dertigjaarstermijn, zoals onder het Oud BW in algemene zin gold. Achtergrond daarvan is dat de verkorting van de lange verjaringstermijn van dertig jaar naar twintig jaar bij invoering van het Nieuw BW voor gevallen van milieuverontreiniging toch te kort werd geacht. Bij milieuverontreiniging (en gevaarlijke stoffen en mijnbouw) komt uit de aard van de zaak schade vaak pas na lange tijd aan het licht. ${ }^{15}$ Denk bijvoorbeeld aan bodemverontreiniging. De dertigjaarstermijn sloot verder aan bij het ontwerp voor het Verdrag van Lugano inzake aansprakelijkheid voor milieurechtelijke activiteiten. ${ }^{16}$ Aan dit (ontwerp)verdrag is ook de

11. HR 28 april 2000, ECLI:NL:HR:2000:AA5635, NJ 2000/430 m.nt. A.R. Bloembergen (Van Hese/De Schelde), r.o. 3.4.

12. Zie bijv. Asser/Sieburgh 6-II 2017/413.

13. Zie Koopmann 2010/19.8.

14. Deze regeling heeft ook betrekking op vorderingen ter zake van gevaarlijke stoffen en mijnbouw die niet op deze artikelen zijn gegrond, maar op onrechtmatige daad of wanprestatie. Zie HR 2 oktober 1998, ECLI:NL:HR:1998:ZC2720, NJ 1999/682 m.nt. J.B.M. Vranken (De Schelde/Wijkhuisen), r.o. 3.6.4, onder verwijzing naar Kamerstukken I 1992/93, 22599, 116b, p. 1, en HR 2 december 2011, ECLI:NL:HR: 2011:BR5216, NJ 2012/197 m.nt. T.F.E. Tjong Tjin Tai (Nefalit/ Schraa), r.o. 3.4.3. Zie tevens Asser/Sieburgh 6-II 2017/413.

15. Zie Kamerstukken II 1992/93, 22599, 3 (MvT) en 5 (MvA). Daarbij speelde mee dat een groot aantal vorderingen van de Staat ter zake van kosten van bodemsanering door de verkorting van de algemene verjaringstermijn van dertig naar twintig jaar dreigde te verjaren. C.C. van Dam, De verjaringstermijn terug naar dertig jaar, NJB 1992, afl. 29, p. 934 .

16. Trb. $1993,149$. specifieke regeling voor aanvang van de dertigjaarstermijn in art. 3:310 lid $3 \mathrm{BW}$ ontleend. Het lid onderscheidt drie typen schadeveroorzakende gebeurtenissen: een plotseling optredend feit, een voortdurend feit en een opeenvolging van feiten met dezelfde oorzaak. Bij een voortdurend feit begint de dertigjaarstermijn te lopen nadat dit feit is opgehouden te bestaan, en bij een opeenvolging van feiten met dezelfde oorzaak na het laatste feit.

In het kindermishandelingsarrest uit 1999 heeft de Hoge Raad deze specifieke regeling restrictief uitgelegd. Wij staan hierbij wat langer stil, omdat hij dit oordeel als gezegd in het arrest Zandvoortse muur nuanceert. In het kindermishandelingsarrest betoogde de benadeelde dat een serie gevallen van kindermishandeling als één schadeveroorzakende gebeurtenis moest worden gezien en dat de twintigjaarstermijn pas na het laatste geval van kindermishandeling was gaan lopen. De benadeelde beriep zich op de regeling voor de aanvang van de lange verjaringstermijn bij milieuverontreiniging van art. 3:310 lid 3 BW (meer specifiek: de regeling in geval van een opeenvolging van feiten met dezelfde oorzaak). De Hoge Raad oordeelde echter dat de wet geen ruimte biedt voor (analoge) toepassing van de regeling voor het aanvangsmoment van de verjaringstermijn in art. 3:310 lid $3 \mathrm{BW}$ buiten gevallen van milieuverontreiniging in de zin van art. 3:310 lid 2 BW:

'Voorzover het onderdeel met een beroep op art. 3:310 lid 3 strekt ten betoge dat het door B. junior gestelde geweld van zijn vader niet is onder te verdelen in afzonderlijke gebeurtenissen van vóór en na 20 mei 1974, doch geheel is aan te merken als één onrechtmatige daad, ziet het onderdeel eraan voorbij dat art. 3:310 lid 3 alleen van toepassing is op de in art. 3:310 lid 2 met zoveel woorden genoemde bedoelde rechtsvorderingen. Zoals mede blijkt uit de in de conclusie van het Openbaar Ministerie onder 8 vermelde wetsgeschiedenis, biedt de wet geen ruimte om ook in andere gevallen dan in genoemde bepaling omschreven, aan te nemen dat een opeenvolging van overeenkomstige onrechtmatige handelingen voor de aanvang van de verjaring als één gebeurtenis moet worden aangemerkt. Het onderdeel faalt derhalve ook in zoverre.' ${ }^{17}$

De conclusie van A-G De Vries Lentsch-Kostense, waarnaar de Hoge Raad verwees, vermeldt over de wetsgeschiedenis van art. 3:310 lid 2 en 3 BW:

'Uit de wettekst en de wetsgeschiedenis blijkt evenwel duidelijk dat deze uitzonderingsregeling alleen geldt voor vorderingen tot vergoeding van schade door milieuverontreiniging en van schade door "gevaarlijke stoffen". Ik verwijs in dit verband met name naar de MvA, p. 4 (Tweede Kamer, vergaderjaar 1992-1993, 22 599, nr. 5), waar wordt opgemerkt dat de uitzonderingsregel van het tweede en derde lid van art. 3:310 een groot deel van de gevallen

17. HR 25 juni 1999, ECLI:NL:HR:1999:ZC2934, NJ 2000/16 (Kindermishandeling), r.o. 5.2. 
van sluipende of sluimerende schade omvat en dat voor uitbreiding daarbuiten geen goede grond bestaat. ${ }^{\text {'18 }}$

Omdat de serie gevallen van kindermishandeling derhalve niet kan worden aangemerkt als één schadeveroorzakende gebeurtenis voor de twintigjaarstermijn, was de uitkomst van het kindermishandelingsarrest dat moest worden nagegaan welk deel van de immateriële schade van de benadeelde kon worden toegerekend aan de niet-'verjaarde' gevallen van kindermishandeling. ${ }^{19}$

Op deze restrictieve lijn kwam kritiek. Die is tweeërlei: ten eerste volgt de restrictieve lijn waarvoor de Hoge Raad koos, niet uit de wetsgeschiedenis. Holthuijsen betoogde kort na het kindermishandelingsarrest dat de passage uit de wetsgeschiedenis die A-G De Vries Lentsch-Kostense aanhaalde, alleen betrekking heeft op uitbreiding van de lengte van de verjaringstermijn van twintig jaar naar dertig jaar en niet op de regeling voor de aanvang van deze termijn. Die regeling zou dus wél ruimer kunnen worden toegepast dan enkel in geval van milieuverontreiniging, aldus Holthuijsen. ${ }^{20}$ Smeehuijzen wijst in zijn proefschrift op praktische en principiële complicaties. ${ }^{21}$ Een praktische complicatie is hoe in een geval als in het kindermishandelingsarrest moet worden bepaald welk deel van de schadevergoedingsvordering niet is verjaard, al dan niet pro rata, op grond van een percentage van het totaal. ${ }^{22}$ Een principiële complicatie is dat voor het bepalen van het niet'verjaarde' deel van de schade het geheel van de schade in aanmerking moet worden genomen. Vervolgens moet worden bepaald welk deel van de schade aan de 'verjaarde' feiten moet worden toegerekend, om te bepalen van welk deel van de schade geen vergoeding meer kan worden gevorderd en van welk deel wél. Daarmee moeten ook feiten worden vastgesteld die meer dan twintig jaar in het verleden liggen, terwijl een belangrijke ratio van de twintigjaarstermijn nu juist is dat door dat grote tijdsverloop die feiten niet meer goed kunnen worden vastgesteld. ${ }^{23}$

Hoe beslissen rechtbank en hof tegen deze achtergrond over het beroep op de lange verjaringstermijn van het flatgebouw in de zaak van de Zandvoortse muur?

18. Conclusie A-G De Vries Lentsch-Kostense voor HR 25 juni 1999, ECLI:NL:HR:1999:ZC2934, NJ 2000/16 (Kindermishandeling), sub 8.

19. Zie conclusie A-G De Vries Lentsch-Kostense voor HR 25 juni 1999 , ECLI:NL:HR:1999:ZC2934, NJ 2000/16 (Kindermishandeling), sub 8.

20. J.L.H. Holthuijsen, Ontsnappen aan het verjaringszwaard, NTBR 2001, afl. 1, p. 5-6.

21. J.L. Smeehuijzen, De bevrijdende verjaring (diss. Amsterdam VU; Serie Recht en Praktijk, deel 162), Deventer: Kluwer 2008.

22. Zie over de pro-ratabenadering J. Spier, Sluipende schade (oratie Tilburg), Deventer: Kluwer 1990, p. 23 e.v. en A.R. Bloembergen, Schadevergoeding bij onrechtmatige daad (diss. Utrecht), Deventer: Kluwer 1965, p. 131-132.

23. Zie Smeehuijzen 2008, p. 265-267.

\section{Het oordeel van de rechtbank en het hof over de lange verjaringstermijn}

Zover ons bekend is het oordeel van de rechtbank in de zaak van de Zandvoortse muur niet gepubliceerd. Uit het arrest van het hof blijkt dat de rechtbank in een tussenvonnis het beroep van het flatgebouw op de lange verjaringstermijn heeft verworpen. De rechtbank oordeelde over de lange verjaringstermijn dat nog niet vaststond dat bij de aanleg van de oprit een fout was gemaakt door de aannemer, zodat het ontstaansmoment van de schadevergoedingsvordering van de parkeergarage nog niet vaststond en daarmee evenmin het aanvangsmoment van de twintigjaarstermijn. Daarmee volgde de rechtbank dus een redenering die veeleer past bij schuldaansprakelijkheid uit onrechtmatige daad, in plaats van risicoaansprakelijkheid op grond van art. 6:174 BW. Daarvoor is immers geen fout vereist. Vervolgens nam de rechtbank aansprakelijkheid van het flatgebouw aan. De rechtbank wees echter geen eindvonnis, omdat zij behoefte had aan deskundigenonderzoek over de kosten van het aanbrengen van een grondkerende voorziening of een andere oplossing. De rechtbank stelde partijen daarom in staat zich uit te laten over de vraag of zij verder wilden procederen en, indien dat het geval was, zich uit te laten over het deskundigenonderzoek. ${ }^{24}$

In hoger beroep brengt het flatgebouw in zijn grief tegen de verwerping van het beroep op verjaring naar voren dat uit het oordeel van de rechtbank over de ansprakelijkheid van het flatgebouw volgt dat de vordering van de parkeergarage wel degelijk verjaard is. De rechtbank nam namelijk aansprakelijkheid aan voor de scheefstand, omdat het flatgebouw bij de bouw van de oprit onvoldoende zorgvuldigheid in acht had genomen. Daaruit volgt dat de schadeveroorzakende gebeurtenis in de zin van art. 3:310 lid $1 \mathrm{BW}$ bestaat in de onjuiste aanleg van de oprit en dus in 1974 heeft plaatsgevonden, zodat de schadevergoedingsvordering van de parkeergarage is verjaard, aldus het flatgebouw. ${ }^{25}$ De parkeergarage brengt daartegen in dat het gebruik van de oprit met auto's en busjes na de aanleg in 1974 de schade heeft veroorzaakt. ${ }^{26}$ Het hof oordeelt daarop dat de gebrekkigheid van de oprit volgens de stellingen van de parkeergarage bestaat in het ontbreken van een grondkerende constructie. Het hof merkt daarom als schadeveroorzakende gebeurtenis in de zin van art. 3:310 lid $1 \mathrm{BW}$ aan:

'de - sinds 1974 voortdurende - aanwezigheid van een oprit zonder grondkerende voorziening en de gronddruk die het gewicht van die oprit, al dan niet in combinatie met dat van voertuigen op de oprit, sinds de aanleg is blijven uitoefenen op de muur'. ${ }^{27}$

24. Hof Amsterdam 23 januari 2019, ECLI:NL:GHAMS:2018:249, r.o. 3.5-3.5.1.

25. Hof Amsterdam 23 januari 2019, ECLI:NL:GHAMS:2018:249, r.o. 3.5.1.

26. Hof Amsterdam 23 januari 2019, ECLI:NL:GHAMS:2018:249, r.o. 3.5.2.

27. Hof Amsterdam 23 januari 2019, ECLI:NL:GHAMS:2018:249, r.o. 3.5.3. 
Het hof vervolgt dat deze schadeveroorzakende gebeurtenis niet uitsluitend in 1974 is te dateren. De schadeveroorzakende gebeurtenis is weliswaar aangevangen in 1974, maar duurt sindsdien voort:

'Deze gebeurtenis is dus niet te dateren in het jaar 1974, althans niet uitsluitend. Met betrekking tot de uitgeoefende gronddruk direct na de aanleg in 1974 is de verjaringstermijn wel toen reeds beginnen te lopen. Het voorgaande betekent dat zal moeten worden bepaald welk deel van de schade is veroorzaakt door het gewicht van de oprit en het gebruik van de oprit in de periode tussen 1974 en 21 mei 1995 (twintig jaar voor de aansprakelijkstelling). Aan de deskundige die zal worden benoemd in het kader van de aansprakelijkheidskwestie (waarover hierna meer) zal ook daarover een vraag moeten worden gesteld. In zoverre slaagt de tweede grief. ${ }^{28}$

Wij begrijpen dit oordeel van het hof zo dat de verjaringstermijn van twintig jaar is gaan lopen direct na de aanleg van de oprit in 1974. Omdat de schadeveroorzakende gebeurtenis daarna voortduurde, is sindsdien, in de ogen van het hof, elke dag opnieuw een nieuwe verjaringstermijn gaan lopen. Met de aansprakelijkstelling van het flatgebouw door de parkeergarage op 21 mei 2015 is de verjaring gestuit tot twintig jaar 'terug', dus vanaf twintig jaar voor de aansprakelijkstelling. Het is aan een deskundige om te bepalen welk deel van de schade is veroorzaakt door enerzijds het gewicht van de oprit en anderzijds het gebruik van de oprit in de periode tussen het moment van aanleg in 1974 en 21 mei 1995. Het oordeel van het hof sluit aan bij de eerder door de Hoge Raad in het kindermishandelingsarrest gevolgde restrictieve benadering, als besproken in paragraaf 2 hiervoor. Op verzoek van het flatgebouw stelt het hof tussentijds cassatieberoep open en daarvan maakt het flatgebouw vervolgens ook gebruik.

\section{Cassatieklachten en conclusie A-G Valk}

Het flatgebouw klaagt in cassatie dat het hof de aanleg van de oprit in 1974 had moeten aanmerken als schadeveroorzakende gebeurtenis, zodat de vordering van de parkeergarage in haar geheel is verjaard. Het flatgebouw beroept zich onder meer op Van Hese/De Schelde: de schadeveroorzakende gebeurtenis moet bestaan in een gedraging - een handelen of nalaten - van de aansprakelijke persoon die tot de schade kan leiden (zie par. 2). ${ }^{29}$ Toegepast op de risicoaansprakelijkheid voor opstallen van art. 6:174 BW brengt dit volgens het flatgebouw met zich dat als schadeveroorzakende gebeurtenis moet worden aangemerkt het doen of nalaten dat tot het gebrek in de opstal heeft geleid waardoor de schade is veroorzaakt. In dit geval: de aanleg van de oprit zonder grondkerende constructie. Het voortdurende karakter van deze gebrekkigheid doet hier volgens het flatgebouw niet aan af, evenmin als het feit dat de

28. Ibid.

29. Conclusie A-G Valk 21 december 2018, ECLI:NL:PHR:2018:1433, sub 3.12 . schade mede wordt veroorzaakt door het gebruik van de oprit. 30

Daarmee komt in cassatie de vraag wat als schadeveroorzakende gebeurtenis in de zin van art. 3:310 lid 1 BW moet worden aangemerkt uitdrukkelijk in het teken te staan van de grondslag van de gestelde aansprakelijkheid: in dit geval de risicoaansprakelijkheid voor opstallen van art. 6:174 BW. De uitleg van het begrip schadeveroorzakende gebeurtenis van Van Hese/De Schelde is in dat kader echter problematisch. De risicoaansprakelijkheid van art. 6:174 $\mathrm{BW}$ is immers niet gebaseerd op enigerlei (onrechtmatige) gedraging van de aangesproken partij. Grondslag van deze risicoaansprakelijkheid is de omstandigheid dat de aansprakelijke persoon een bepaalde goederenrechtelijke hoedanigheid heeft: bezitter van een opstal die schade veroorzaakt. In termen van art. 6:174 lid 1 BW: bezitter van een opstal die niet voldoet aan de daaraan in de gegeven omstandigheden te stellen eisen, daardoor een gevaar in het leven roept voor personen of zaken, en schade veroorzaakt doordat dit gevaar zich verwezenlijkt.

Daarop wijst ook A-G Valk in zijn conclusie. Hij stelt voorop dat het beroep van het flatgebouw op het arrest Van Hese/De Schelde niet opgaat, omdat dit arrest ziet op werkgeversaansprakelijkheid (onder het Oud BW) - schuldaansprakelijkheid - en niet op art. 6:174 BW. Valk loopt vervolgens de elementen van art. 6:174 BW af en zoekt daarbij naar een gebeurtenis. Hij constateert dat de elementen dat de opstal gebrekkig is en daardoor een gevaar vormt voor personen of zaken een 'toestand' betreffen waarin de opstal verkeert en geen gebeurtenis. Alleen het derde element, de verwezenlijking van het gevaar dat door de gebrekkigheid in het leven wordt geroepen, kan in zijn optiek als een gebeurtenis worden aangemerkt. Volgens Valk moet daarom die verwezenlijking van het gevaar worden aangewezen als schadeveroorzakende gebeurtenis in de zin van art. 3:310 lid $1 \mathrm{BW} .^{31}$

Het oordeel van het hof strookt hiermee, zo vervolgt Valk. Dat wil zeggen: het oordeel van het hof dat niet de aanleg van de oprit de schadeveroorzakende gebeurtenis is, maar de gronddruk die vanaf het moment van gereedkomen van de oprit op de muur is uitgeoefend doordat een grondkerende voorziening ontbreekt. Valk wijst er daarbij op dat de opvatting van het flatgebouw dat de aanleg van de oprit zonder grondkerende constructie als schadeveroorzakende gebeurtenis moet worden aangemerkt waardoor de vordering van de parkeergarage geheel verjaard zou zijn, zou resulteren in een uitkomst die niet in lijn is met de ratio van art. 6:174 BW. De bezitter heeft profijt van de opstal. De bezitter moet daarom ook de lasten van de opstal dragen (gespreid via verzekering), bestaande in eventueel daardoor veroorzaakte schade, en niet een toevallige benadeelde die niet in een bijzondere relatie

30. Conclusie A-G Valk 21 december 2018, ECLI:NL:PHR:2018:1433, sub 3.9.

31. Conclusie A-G Valk 21 december 2018, ECLI:NL:PHR:2018:1433, sub 3.12 . 
staat tot de opstal. Dat geldt ook als het gebrek aan de opstal meer dan twintig jaar geleden is ontstaan. ${ }^{32}$

A-G Valk laat zich niet uit over het oordeel van het hof dat de schadevergoedingsvordering van de parkeergarage deels is verjaard en deels niet. Reden daarvoor is dat in zijn optiek na het eindvonnis de parkeergarage op dat punt nog cassatieberoep zal kunnen instellen. ${ }^{33}$ Valk concludeert aldus tot verwerping van het cassatieberoep.

\section{Oordeel van de Hoge Raad}

De Hoge Raad vaart een gedeeltelijk andere koers dan zijn advocaat-generaal. Ook de Hoge Raad verwerpt het betoog van het flatgebouw dat op grond van Van Hese/De Schelde de schadeveroorzakende gebeurtenis moet bestaan in een gedraging en om die reden de aanleg van de oprit als zodanig moet worden aangewezen. Hij doet dat echter impliciet, want de Hoge Raad noemt Van Hese/De Schelde niet. Hij stelt de wetsgeschiedenis van art. 3:310 lid $1 \mathrm{BW}$ voorop. De wetgever heeft in de uiteindelijke wetstekst uitdrukkelijk gekozen voor een schadeveroorzakende 'gebeurtenis' als aanvangsmoment voor de twintigjaarstermijn en niet voor een 'handeling' zoals in het oorspronkelijke ontwerp:

'Een rechtsvordering tot vergoeding van schade verjaart op grond van art. 3:310 lid $1 \mathrm{BW}$ in ieder geval door verloop van twintig jaren na de gebeurtenis waardoor de schade is veroorzaakt. Uit de parlementaire geschiedenis van deze bepaling blijkt dat de verjaringstermijn van twintig jaren volgens het oorspronkelijke ontwerp zou lopen vanaf de "handeling" waardoor de schade is veroorzaakt. De wetgever heeft deze redactie verlaten omdat noch in titel 6.3 BW noch bij wanprestatie de verplichting om schade te vergoeden steeds en uitsluitend verbonden is aan een "handeling" die deze heeft veroorzaakt (Parl. Gesch. Boek 3, p. 925). 34

Uit de wetsgeschiedenis van art. 3:310 BW volgt dus - wij nemen althans aan dat de Hoge Raad dat bedoelt te zeggen dat de schadeveroorzakende gebeurtenis niet een gedraging hoeft te zijn.

Vervolgens gaat de Hoge Raad in op de aard en systematiek van art. 6:174 BW. Hij overweegt dat de grondslag van de risicoaansprakelijkheid voor opstallen niet een gedraging is van de aangesproken partij. Er is daarom 'geen reden' waarom het hof in het kader van de schadevergoedingsvordering van de parkeergarage op grond van art. 6:174 BW de aanleg van de oprit als schadeveroorzakende gebeurtenis had moeten aanmerken en daarmee faalt de klacht van het flatgebouw:

32. Conclusie A-G Valk 21 december 2018, ECLI:NL:PHR:2018:1433, sub 3.16-3.17.

33. Conclusie A-G Valk 21 december 2018, ECLI:NL:PHR:2018:1433, sub 3.13 en voetnoot 2.

34. HR 22 maart 2019, ECLI:NL:HR:2019:412, RvdW 2019/394 (Zandvoortse muur), r.o. 3.3.2.
'De bezitter van een opstal die gevaar oplevert voor personen of zaken doordat deze niet voldoet aan de eisen die men daaraan in de gegeven omstandigheden mag stellen, is op grond van art. 6:174 lid $1 \mathrm{BW}$ aansprakelijk indien dat gevaar zich verwezenlijkt. Het aannemen van deze aansprakelijkheid is dus niet verbonden aan een schadeveroorzakende gedraging, maar aan de schadeveroorzakende toestand waarop art. 6:174 BW ziet. Het doet niet ter zake of die toestand is veroorzaakt door enige gedraging. Daarom is er wat deze aansprakelijkheid betreft geen reden om een gedraging - in dit geval de aanleg van de oprit zonder grondkerende constructie - aan te merken als schadeveroorzakende gebeurtenis waardoor de verjaringstermijn van twintig jaren gaat lopen. Onderdeel 2 faalt dan ook.' 35

Omdat de Hoge Raad als gezegd (zie par. 1) ook de klachten verwerpt over het oordeel van het hof dat het flatgebouw zich niet kan beroepen op de korte, subjectieve verjaringstermijn van vijf jaar, is daarmee het hele cassatieberoep van het flatgebouw verworpen. De Hoge Raad geeft echter nog twee overwegingen ten overvloede over de vraag wanneer in een zaak als de Zandvoortse muur de twintigjaarstermijn begint te lopen.

In de eerste overweging stelt hij in algemene zin voorop dat de twintigjaarstermijn de rechtszekerheid dient en daarom voor het aanvangsmoment van deze termijn 'het objectief gegeven tijdstip waarop de gebeurtenis plaatsvond' beslissend is, onder verwijzing naar het kindermishandelingsarrest. ${ }^{36}$ In de tweede overweging ten overvloede resumeert hij de gebeurtenis die het hof heeft aangewezen als schadeveroorzakende gebeurtenis, en overweegt hij dat deze gebeurtenis 'in deze zaak' een voortdurend 'karakter' heeft. Dat karakter brengt met zich dat de gebeurtenis 'niet tot één moment kan worden herleid'. Omwille van de rechtszekerheid moet daarom in een geval als dit' worden aangenomen dat de twintigjaarstermijn begint te lopen zodra de schadeveroorzakende gebeurtenis 'is opgehouden te bestaan', aldus de Hoge Raad:

'Het hof heeft als gebeurtenis waardoor de schade is veroorzaakt, aangemerkt de - sinds 1974 voortdurende aanwezigheid van een oprit zonder grondkerende voorziening en de gronddruk die het gewicht van die oprit, al dan niet in combinatie met dat van voertuigen op die oprit, sinds de aanleg is blijven uitoefenen op de muur. Het voortdurende karakter van de aldus vastgestelde gebeurtenis in deze zaak brengt mee dat die gebeurtenis niet tot één moment kan worden herleid. Als gevolg hiervan bestaat onzekerheid over het aanvangstijdstip van de twintigjarige verjaring. Dat verdraagt zich niet met het aan die termijn ten grondslag liggende belang van de rechtszekerheid (zie hiervoor in 3.5.1). Daarom moet in een geval als dit wor-

35. HR 22 maart 2019, ECLI:NL:HR:2019:412, RvdW 2019/394 (Zandvoortse muur), r.o. 3.3.3.

36. HR 22 maart 2019, ECLI:NL:HR:2019:412, RvdW 2019/394 (Zandvoortse muur), r.o. 3.5.1. 
den aangenomen dat de termijn van twintig jaren begint te lopen zodra de gebeurtenis waardoor de schade is veroorzaakt, is opgehouden te bestaan. ${ }^{37}$

Hoewel de Hoge Raad dit oordeel al motiveert aan de hand van het voortdurende karakter van de schadeveroorzakende gebeurtenis in deze zaak en meer specifiek het feit dat die gebeurtenis niet tot een moment kan worden herleid, voegt hij daaraan nog een nadere motivering toe. Hij zoekt aansluiting bij de specifieke regeling voor aanvang van de dertigjarige verjaringstermijn bij milieuverontreiniging in art. 3:310 lid 3 $\mathrm{BW}$, onder nuancering 'in zoverre' van zijn restrictieve oordeel in het kindermishandelingsarrest dat de regeling van lid 3 alleen van toepassing is op de in lid 2 met zoveel woorden genoemde rechtsvorderingen:

'Dit strookt met hetgeen in art. 3:310 lid $3 \mathrm{BW}$ is geregeld voor de in art. 3:310 lid $2 \mathrm{BW}$ genoemde gevallen. Het oordeel in HR 25 juni 1999, ECLI:NL:HR: 1999:ZC2934, rov. 5.2, dat het in art. 3:310 lid 3 BW bepaalde alleen geldt voor de in art. 3:310 lid 2 BW met zoveel woorden genoemde rechtsvorderingen, behoeft dus in zoverre nuancering. $Z$ ie in verband hiermee ook de parlementaire geschiedenis van de Wet van 24 december 1992, Stb. 691 betreffende de verjaring van de vordering tot vergoeding van schade door milieuverontreiniging. Daaruit blijkt dat aannemelijk is dat het in art. 3:310 lid 3 BW bepaalde overeenkomt met het voor invoering van die bepaling voor verjaring in het algemeen reeds geldende recht. (Kamerstukken II 1992/93, 22599, nr. 5, p. 5) ) $^{38}$

In het hierboven weergegeven citaat geeft de Hoge Raad bovendien ook nog een motivering voor zijn nuancering van het kindermishandelingsarrest: een motivering van de motivering als het ware. De Hoge Raad leidt uit hetzelfde Kamerstuk als waarop hij zich destijds in het kindermishandelingsarrest (via de conclusie van A-G De Vries Lentsch-Kostense) beriep voor zijn restrictieve lijn dat lid 3 niet buiten gevallen van milieuverontreiniging mag worden toegepast, nu iets heel anders af. Hij overweegt dat 'aannemelijk' is dat 'het in art. 3:310 lid 3 BW bepaalde' al geldend recht was voor 'verjaring in het algemeen' vóórdat deze bepaling werd ingevoerd. In het vervolg van deze bijdrage geven wij onze observaties bij dit oordeel van de Hoge Raad, waaronder deze opvallende uitsmijter.

\section{Observaties over implicaties}

Wat is nu de betekenis van het arrest van de Hoge Raad over de Zandvoortse muur? Het arrest makt allereerst duidelijk dat het begrip schadeveroorzakende gebeurtenis in de zin van art. 3:310 lid $1 \mathrm{BW}$ niet per se een gedraging van de aangesproken partij hoeft te zijn. Het begrip schadeveroorzakende gebeurtenis moet worden uitgelegd in het licht van de grond-

37. HR 22 maart 2019, ECLI:NL:HR:2019:412, RvdW 2019/394 (Zandvoortse muur), r.o. 3.5.2.

38. Ibid. slag van de (gestelde) aansprakelijkheid waarop de schadevergoedingsvordering berust. In de zaak van de Zandvoortse muur is die grondslag de risicoaansprakelijkheid voor opstallen van art. 6:174 BW. In dat kader moet als schadeveroorzakende gebeurtenis worden aangemerkt de schadeveroorzakende toestand waarin de opstal verkeert. Preciezer gezegd: het moment dat het gevaar dat de opstal door zijn gebrekkigheid in het leven roept, zich verwezenlijkt. Dat hoeft niet hetzelfde moment te zijn als het moment vanaf welke de opstal gebrekkig is en daardoor een gevaar in het leven roept. Het kan immers zijn dat een gebouw van meet af aan gebrekkig is en daardoor een gevaar in het leven roept (bijvoorbeeld een vanaf het gereedkomen van de bouw bestaand instortingsgevaar door een constructiefout), maar dat gevaar zich pas later verwezenlijkt (bijvoorbeeld bij storm).

De vraag wanneer de twintigjaarstermijn begint te lopen, is daarmee in een zaak als die van de Zandvoortse muur echter nog niet beantwoord. Het moment waarop de opstal gebrekkig wordt en daardoor een gevaar in het leven roept én dat gevaar zich verwezenlijkt, lopen in dit geval gelijk op. Uitgaande van het oordeel van het hof is dit het moment waarop de oprit werd aangelegd zonder grondkerende constructie. Vanaf dat moment was de oprit (volgens de stellingen van de parkeergarage) gebrekkig, riep deze een gevaar in het leven voor schade aan de muur van de parkeergarage en verwezenlijkte dat gevaar zich in de vorm van een gronddruk die op de muur werd uitgeoefend, waardoor de muur steeds schever kwam te staan. Wat de vraag naar het aanvangsmoment ingewikkeld maakt, is dat de scheefstand is veroorzaakt in een doorlopend proces dat lang voortduurt, langer zelfs dan de twintigjaarstermijn zelf. Als dan de tekst van art. 3:310 lid $1 \mathrm{BW}$ letterlijk wordt gevolgd en wordt aangenomen dat de twintigjaarstermijn begint te lopen 'na' dit doorlopende proces, zou dat betekenen dat een schadevergoedingsvordering op grond van art. 6:174 BW in een zaak als de Zandvoortse muur niet verjaart ondanks het verstrijken van de volle twintigjaarstermijn. Dat verhoudt zich echter slecht met de ratio van deze termijn van het bieden van rechtszekerheid en het voorkomen dat een vordering moet worden beoordeeld op grond van feiten die vanwege dit lange tijdsverloop niet meer goed kunnen worden vastgesteld. ${ }^{39}$

Wat dat betreft is het begrijpelijk dat het hof met zijn oordeel dat de schadevergoedingsvordering van het flatgebouw gedeeltelijk is verjaard, koos voor een tussenoplossing. De redenering die het hof daartoe volgt, doet denken aan de lijn die de Hoge Raad volgde in het recente arrest TMG/Staat met betrekking tot de verjaring op grond van de korte vijfjaarstermijn van een vordering tot schadevergoeding vanwege niet-tijdige implementatie van een richtlijn. ${ }^{40}$ De Hoge Raad oordeelde dat zolang geen juiste implementatie van een Europese richtlijn

39. Vgl. D.F.H. Stein, Verjaring van schadevergoedingsvorderingen bij voortdurende onrechtmatige daden, NTBR 2019, afl. 4, p. 71.

40. HR 4 mei 2018, ECLI:NL:HR:2018:677, NJ 2018/239, AB 2018/300 m.nt. R.J.G.M. Widdershoven (TMG/Staat). 
plaatsvindt, dit iedere dag een zelfstandige onrechtmatige daad van de Staat oplevert, zodat daarop gegronde vorderingen afzonderlijk verjaren. A-G Van Peursem betoogde in zijn conclusie voorafgaand aan het arrest dat de gestelde omzettingsfout van de Staat een 'eenmalige gebeurtenis is', omdat het andersluidende betoog van eiser ertoe zou leiden dat de korte verjaringstermijn in een groot deel van de gevallen zijn betekenis zou verliezen, nu bij een voortdurende gebeurtenis de verjaringstermijn steeds opnieuw gaat lopen na iedere dag dat de onrechtmatigheid niet is weggenomen. ${ }^{41}$ De Hoge Raad ging in TMG/Staat aan dat bezwaar voorbij, waarbij hij meewoog dat ook het in stand houden van onrechtmatige wetgeving op zichzelf een onrechtmatige daad door de Staat vormt. De verplichting een richtlijn juist te implementeren omvat mede de verplichting na een onjuiste implementatie alsnog juist te implementeren. ${ }^{42}$

Annotator Stein wierp de vraag op of deze benadering ook zou kunnen worden gevolgd bij de twintigjaarstermijn. ${ }^{43}$ Het hof doet dat dus. In een geval als dat van de Zandvoortse muur ligt een pro-ratabenadering als in TMG/Staat en als toegepast door het hof wat ons betreft echter minder voor de hand. Bij de Zandvoortse muur is geen sprake van een voortdurende schending van een gedragsnorm - zoals bij het verzuim van de Staat hogere regelgeving tijdig en juist te implementeren en ook na de implementatiedatum de wetgeving in lijn met Europees recht te houden - maar van een risicoaansprakelijkheid die is gebaseerd op de hoedanigheid van bezitter van een schadeveroorzakende opstal. Daartegenover zou kunnen worden gesteld dat ook art. 6:174 BW een dergelijke voortdurende grondslag voor aansprakelijkheid vormt, nu die aansprakelijkheid bestaat zolang de aansprakelijke partij bezitter is van een gebrekkige, schadeveroorzakende opstal.

Naast de aard van de aansprakelijkheid is er echter nog een verschil tussen TMG/Staat en de Zandvoortse muur: de aard van de schade en de wijze van ontstaan van de schade. Het gaat bij de Zandvoortse muur niet om dagelijkse 'porties' zuivere vermogensschade, die als het ware elke dag opnieuw ontstaan omdat het nationale recht niet in overeenstemming is met het Europese recht. Het gaat om een en dezelfde zaakschade veroorzaakt in een doorlopend fysiek proces, dat in de treffende woorden van de Hoge Raad niet 'tot één moment valt te herleiden'. Het opknippen van een en dezelfde zaakschade in een 'verjaard' en een 'niet-verjaard' deel alleen omdat de totale periode van schadeveroorzaking 'toevallig' langer is dan de verjaringstermijn van twintig jaar, lijkt ons in de zaak van de Zandvoortse muur daarom arbitrair, of in elk geval meer arbitrair dan bij zuivere vermogensschade in een geval als TMG/ Staat. Zou die benadering worden toegepast bij de twintigjaarstermijn, zoals het hof doet in de Zandvoortse muur, dan

41. Conclusie A-G van Peursem 26 januari 2018, ECLI:NL:PHR:2018:84, par. 4.15 .

42. HR 4 mei 2018, ECLI:NL:HR:2018:677, NJ 2018/239, AB 2018/300 m.nt. R.J.G.M. Widdershoven (TMG/Staat), r.o. 3.4.1-3.4.2.

43. D.F.H. Stein, noot onder TMG/Staat, O\&A 2018/53, sub 9. geldt bovendien het bezwaar van Smeehuijzen dat voor het bepalen van het niet-verjaarde deel het geheel in aanmerking moet worden genomen en daarmee ook 'verjaarde' feiten, terwijl de twintigjaarstermijn dat nu juist beoogt te voorkomen (zie par. 3). Daar komt nog de praktische complicatie bij dat in dit soort gevallen wellicht moeilijk zal zijn vast te stellen welk gedeelte van de schade moet worden toegerekend aan het 'verjaarde' deel van de feiten en welk gedeelte aan het 'niet-verjaarde' deel. Het zal aankomen op deskundigenverklaringen. ${ }^{44}$

Per saldo kunnen wij ons daarom vinden in de oplossing die de Hoge Raad kiest. In een geval als dat van de Zandvoortse muur begint de twintigjaarstermijn te lopen zodra de schadeveroorzakende gebeurtenis is opgehouden te bestaan. In termen van de aard van de aansprakelijkheid, de aard van de schade en de wijze van ontstaan van schade gaat het dan om het gevalstype van een vordering op grond van de risicoaansprakelijkheid voor opstallen van art. 6:174 BW tot vergoeding van zaakschade (scheefstand van de muur) die is ontstaan in een doorlopend fysiek proces (de voortdurende gronddruk). Dit gevalstype laat zich inhoudelijk ook vergelijken met gevallen van milieuverontreiniging, waarin de schade ook niet zelden in een langdurig doorlopend fysiek proces wordt veroorzaakt. Voor zulke gevallen heeft de wetgever bepaald dat in geval van een voortdurend feit de lange verjaringstermijn aanvangt nadat dit feit heeft opgehouden te bestaan. Dat brengt ons bij de aansluiting die de Hoge Raad zoekt bij de regeling voor de aanvang van de dertigjaarstermijn bij een schadeveroorzakende gebeurtenis die bestaat in een voortdurend feit in gevallen van milieuverontreiniging van art. 3:310 lid 3 BW.

\section{Een U-bocht en een uitsmijter}

Inhoudelijk is het niet zo gek dat de Hoge Raad voor zijn oordeel in de zaak van de Zandvoortse muur aansluiting zoekt bij de regeling voor het aanvangsmoment van de lange verjaringstermijn in gevallen van milieuverontreiniging. De vraag is of het uitdrukkelijk noemen van lid 3 daarvoor nodig was geweest. Immers, een letterlijke lezing van art. 3:310 lid 1 BW, dat de twintigjaarstermijn gaat lopen 'na' de schadeveroorzakende gebeurtenis, had ook tot de conclusie kunnen leiden dat die gebeurtenis eerst moet zijn geëindigd. In combinatie met het oordeel dat de schadeveroorzakende gebeurtenis in het kader van art. 6:174 BW moet worden opgevat als het moment - of de voortdurende toestand - van verwezenlijking van het gevaar dat de opstal door zijn gebrekkigheid in het leven roept, was in de zaak van de Zandvoortse muur dan dezelfde uitkomst bereikt.

Door echter uitdrukkelijk aansluiting te zoeken bij lid 3 dwingt de Hoge Raad zichzelf als het ware een U-bocht te maken vanwege zijn restrictieve lijn in het kindermishandelingsarrest. Daarin had hij immers geoordeeld dat er juist geen ruimte is om de regeling voor de aanvang van de twintigjaarstermijn toe te passen buiten gevallen van milieuverontreini-

44. Stein 2019 , p. $65-66$ 
ging in de zin van lid 2. In het gevalstype van de Zandvoortse muur is er nu wél ruimte om de regeling voor de aanvang van de lange verjaringstermijn bij schade veroorzaakt door een voortdurend feit van lid 3 analoog toe te passen - dan wel bij de toepassing van lid 1 tot dezelfde uitkomst te komen -, ook al ziet de schadevergoedingsvordering van de parkeergarage niet op milieuverontreiniging. Of beter gezegd, de Hoge Raad maakt die ruimte alsnog. Of en in hoeverre dit oordeel van de Hoge Raad in de Zandvoortse muur ook buiten het specifieke gevalstype dat daarin aan de orde is, houdbaar is, moet wat ons betreft nog blijken. De Hoge Raad spitst zijn overweging over de aanvang van de twintigjaarstermijn nadrukkelijk toe op 'deze zaak' en 'een geval als dit' en spreekt van nuancering 'in zoverre' - en dus niet verder - van het kindermishandelingsarrest.

Wij gaan er daarom ook van uit dat de Hoge Raad alleen ruimte heeft gemaakt om buiten gevallen van milieuverontreiniging aansluiting te zoeken bij de regeling voor de aanvang van de lange verjaringstermijn in lid 3, voor zover de schadeveroorzakende gebeurtenis een voortdurend feit is (en dus niet in het geval van een opeenvolging van feiten met dezelfde oorzaak). Ook al onderbouwt de Hoge Raad zijn geclausuleerde nuancering van het kindermishandelingsarrest in nogal algemene termen in de uitsmijter waarmee hij zijn overwegingen ten overvloede afsluit. Die komt erop neer dat 'het in art. 3:310 lid 3 BW bepaalde' - in algemene zin dus - al voor invoering ervan geldend recht zou zijn geweest, niet alleen op het vlak van milieuverontreiniging, maar voor 'verjaring in het algemeen', het hele verjaringsrecht dus. De Hoge Raad zou dan niet alleen het kindermishandelingsarrest deels nuanceren, maar in wezen de hele invoering van de regeling van de aanvang van de lange verjaringstermijn bij milieuverontreiniging in lid 3. Omdat de Hoge Raad echter zijn overwegingen ten overvloede tot aan deze uitsmijter telkens uitdrukkelijk toespitst op het specifieke gevalstype van de Zandvoortse muur en deze dient ter onderbouwing van zijn geclausuleerde nuancering 'in zoverre' van het kindermishandelingsarrest, gaan wij ervan uit dat ook de uitsmijter in deze terughoudende zin moet worden gelezen.

Overigens zijn wij er nog niet van overtuigd dat 'aannemelijk' is dat het bepaalde in lid 3 al voor invoering van deze bepaling geldend recht was en de invoering van dit lid dus pure codificatie was, zoals de Hoge Raad overweegt. Toegegeven, in het Kamerstuk waarop de Hoge Raad zich beroept, kan inderdaad worden gelezen dat 'aannemelijk' is dat het bepaalde in lid 3 'overeenstemt met het huidige recht' en 'strikt genomen' dus 'overbodig' zou zijn. ${ }^{45}$ De minister baseert dit in het desbetreffende Kamerstuk mede op een publicatie van Spier in het WPNR, die echter schrijft dat de nieuwe regeling van lid 2 en 3 strookt met de zijns inziens 'wenselijke uitleg van het huidige art. 3:310', en dus niet per se met het destijds geldend recht. ${ }^{46}$

45. Kamerstukken II 1992/93, 22599, 5, p. 5.

46. J. Spier, Gecompliceerde verjaringskwesties, WPNR 1992/6059, p. 591 (curs. BB \& PWdH)
Verder is de vraag of met de passage in het Kamerstuk waarnaar de Hoge Raad verwijst, wordt bedoeld dat de regel dat de verjaringstermijn bij een voortdurend feit gaat lopen nadat dit feit is opgehouden te bestaan, al gold voor het bestaande recht in algemene zin, zoals de Hoge Raad overweegt, of enkel op het vlak van milieuverontreiniging. Die lezing is óók mogelijk. Misschien is die zelfs aannemelijker, omdat het bepaalde in lid 3 is ontleend aan het ontwerp voor het Verdrag van Lugano over aansprakelijkheid voor milieurechtelijke activiteiten. ${ }^{47}$

Hetzelfde Kamerstuk bevat bovendien passages die erop wijzen dat lid 2 en 3 wel degelijk limitatief zijn bedoeld voor de gevallen omschreven in lid 2. Zo valt erin te lezen dat voor een uitbreiding van de regeling buiten de gevallen van lid 2 'onvoldoende grond' bestaat. ${ }^{48}$ Op grond van die passage concludeerde A-G De Vries Lentsch-Kostense in haar conclusie voor het kindermishandelingsarrest nu juist dat lid 2 en 3 enkel zijn bedoeld voor gevallen van milieuverontreiniging, welke lezing door de Hoge Raad in het kindermishandelingsarrest (nog) werd gevolgd. Op die lezing kwam in de literatuur als gezegd echter ook direct kritiek, met name dat deze passage enkel ziet op de lengte van de lange verjaringstermijn - voor verdere uitbreiding van de termijn van twintig jaar naar dertig jaar bestaat onvoldoende grond - en niet op het aanvangsmoment (zie par. 3). Zoveel is zeker: het is niet evident hoe de wetsgeschiedenis van lid 2 en 3 op dit punt moet worden geïnterpreteerd. Bij de uitsmijter van de Hoge Raad dat het aannemelijk is dat het bepaalde in lid 3 voor invoering daarvan al gold voor 'verjaring in het algemeen', zijn vraagtekens te plaatsen.

Inmiddels is in de literatuur echter ook anders betoogd, zowel over de reikwijdte van de overweging dat de twintigjaarstermijn begint te lopen zodra de schadeveroorzakende gebeurtenis heeft opgehouden te bestaan, als over de verwijzing naar (de wetsgeschiedenis van) art. 3:310 lid 3 BW. Stein wijst er - op zichzelf terecht - op dat de clausuleringen die de Hoge Raad in zijn overwegingen ten overvloede heeft aangebracht, er niet aan afdoen dat de rechtszekerheids-, wetssystematische en wetshistorische argumenten die de Hoge Raad geeft, ook opgaan voor andere gevalstypen dan dat van de Zandvoortse muur, of in de woorden van Stein: van 'voortdurende onrechtmatige daden'. Stein betoogt daarom dat het arrest over de Zandvoortse muur juist een brede strekking heeft, en meent dat de Hoge Raad met zijn uitsmijter over de wetsgeschiedenis van art. 3:310 lid 3 BW terecht de 'fout' van het kindermishandelingsarrest heeft rechtgezet. ${ }^{49}$

\section{Besluit}

Het arrest van de Hoge Raad in de zaak van de Zandvoortse muur is opvallend. De Hoge Raad verwerpt de cassatieklachten van het flatgebouw dat de aanleg van de oprit als schadeveroorzakende gebeurtenis in de zin van art. 3:310 lid 1 BW

\footnotetext{
47. Vgl. Spier 1992, p. 591, voor wie niet evident is dat lid 3 codificatie is van destijds al geldend verjaringsrecht.

48. Kamerstukken II 1992/93, 22599, 5, p. 4 .

49. Zie Stein 2019, p. 67-71.
} 
had moeten worden aangemerkt, maar komt daarmee niet toe aan beantwoording van de vraag wanneer in een geval als dit de twintigjaarstermijn begint te lopen. Die vraag beantwoordt hij vervolgens in twee overwegingen ten overvloede. Ongevraagd, want er was geen cassatiemiddel dat daarom vroeg en het gaat ook niet om een prejudiciële-vragenprocedure. Is dat wenselijk? Het is in elk geval verwarrend, omdat de Hoge Raad tot een andere uitkomst komt dan het hof, maar het arrest van het hof niet kan worden vernietigd. Het is ook de vraag of de Hoge Raad in deze procedure niet te veel voor de troepen uit loopt. A-G Valk beperkte zich welbewust tot de cassatieklachten en liet zich niet uit over de vraag naar het aanvangsmoment van de twintigjaarstermijn, omdat daarover mogelijk later nog een cassatieberoep kan worden ingesteld (zie par. 4). De gedachte van de Hoge Raad zal allicht zijn geweest dat hij (alvast) een openstaande rechtsvraag heeft beantwoord. Dat mag zo zijn, maar de vraag is of dit nu het meest geschikte moment was, en of de Hoge Raad zich niet wat terughoudender had moeten opstellen.

Wat het arrest van de Zandvoortse muur in onze optiek verder toont, is dat beantwoording van openstaande rechtsvragen niet zelden weer nieuwe vragen oproept, naar de reikwijdte van de nieuw geformuleerde rechtsregel. Zeker als de formulering niet steeds even strak is. Wij denken dat de Hoge Raad zijn overweging ten overvloede dat de twintigjaarstermijn bij voortdurende schadeveroorzaking aanvangt nadat de schadeveroorzakende gebeurtenis heeft opgehouden te bestaan, uitdrukkelijk in het teken stelt van het specifieke gevalstype in de zaak van de Zandvoortse muur: een vordering op grond van art. 6:174 BW tot vergoeding van zaakschade, die is veroorzaakt in een doorlopend fysiek proces dat niet tot een moment valt te herleiden. In dat specifieke licht moet het wat ons betreft ook worden begrepen, mede gezien de ratio van de twintigjaarstermijn om juist te voorkomen dat een vordering kan worden ingesteld op grond van feiten die zich vanwege dit lange tijdsverloop niet meer goed laten vaststellen. De in algemenere termen geformuleerde uitsmijter over de wetsgeschiedenis van art. 3:310 lid $3 \mathrm{BW}$ doet hieraan wat ons betreft niet af en zou dat ook niet moeten doen. Over de reikwijdte van het arrest over de Zandvoortse muur wordt als gezegd echter ook anders gedacht. Het debat gaat dus voort. 